\title{
Features of the formation of highest nobility estates in the neighboring districts of the St. Petersburg province
}

\author{
Ekaterina Kozyreva ${ }^{1, *}$ \\ ${ }^{1}$ St. Petersburg State University of Architecture and Civil Engineering, St. Petersburg, Russia
}

\begin{abstract}
The paper is devoted to studies of the location until 1917 in the neighboring districts (Peterhof, Tsarskoye Selo, Shlisselburg and St. Petersburg) of St. Petersburg province of large, representative and prestigious suburban estates - "estates of the highest nobility". Such representative estates received special material and intangible characteristics that distinguish them from "ordinary" estates. Typical examples are considered: Grevov's estate in Koporye, Shuvalovs' estate (of Vorontsova-Dashkova E.A.) "Pargolovo", Belogorka estate, Irinovka estate. The relevance of the work is caused by the fact that an active search for ways to adjust estates is currently underway. To carry out these works, it is necessary to understand the unique features of adjustment objects. In the European and domestic practice of adjustment of objects, special attention is paid to estates belonging to the upper strata of society (in prerevolutionary Russia, to the nobility). The purpose of the study is to identify a separate type of object "near estates of the highest nobility". Results preserved and existed earlier estates of the highest nobility are analyzed. The regularities of the formation of features and characteristics are revealed, which allows distinguishing them into a separate type of objects - "near estates of the highest nobility".
\end{abstract}

\section{Introduction}

During the formation and development of St. Petersburg from 1703 to 1917, a ring of suburban estates of the highest nobility of St. Petersburg gradually formed around the city. Such estates differed from thousands of ordinary urban ones, suburban and rural estates in the functional, spatial and compositional features that eminent architects created for the owners. (Sergey Sementsov, 2019).

Hundreds of noble estates, which were studied in sufficient detail in the works of I.V. Barsova, S.E. Guseva, T.E. Isachenko, O.V. Litvintseva, indicated in general works on the theory and history of architecture and landscape art TB Dubyago, A.V. Ikonnikov, M.A. Ilyin, T.P. Kazhdan, V.Ya. Kurbatov and others; in works devoted to Russian estates I.A. Bondarenko, T.P. Kazhdan, A.Yu. Nizovsky and others; in books and articles on the history

\footnotetext{
* Corresponding author: ket007@mail.ru
} 
of St. Petersburg that contain information about the estates of Georgi, M.I. Pylyaev, N.N. Wrangel, N.V. Murashova, L.P. Myslina, S.V. Sementsov et al.

\section{Subject, tasks and methods}

Near estates of the highest nobility in the territory of Peterhof, Tsarskoye Selo, Shlisselburg and St. Petersburg counties. The objective of the work is to identify patterns of placement and search for features of estates of the highest nobility around St. Petersburg. It is based on the study of numerous complex historical materials, including extensive collections of cartographic and descriptive data stored in various archives and libraries of St. Petersburg. Including performed field studies.

\section{Research Results and Discussion}

A. Territorial features of the placement of estates of the highest nobility.

By 1917, there were about two thousand estates in the St. Petersburg province. Among them were various objects, both the imperial palace and park residences, and the modest dwellings of rural landowners. To date, on the territory of the modern center of St. Petersburg, in the areas of its near and distant suburbs, in the distant regions of the modern Leningrad region (until 1917 - the districts of the St. Petersburg province), hundreds of noble estates have remained, although in different conditions. Among them ones, which were investigated in sufficient detail by I.V. Barsova, S.E. Guseva, T.E. Isachenko, O.V. Litvintseva (Barsova, 1971; Guseva, 2008; Isachenko, 2003; Litvintseva O.V., 2006). In all the works, estates were discovered, the owners of which were the most influential persons and families of Russia. Manors that were especially large, a more diverse "set" of buildings, structures, natural and man-made landscapes.

In my research, such unique estates are defined as "estates of the highest nobility" ("nearby estates of the highest nobility"). (Kozyreva, 2016).

Earlier research N.Ya. Tikhomirova estates near Moscow made it possible to identify estates in Moscow that were similar in size and structural diversity. In his studies, the estates are structured and characterized according to the social status and noble sociopolitical responsibilities of the estates' owner. The dependence of the area, the number of buildings and the internal layout of the main estate building, the nature of the park buildings on the status of the owner are also shown. (Tikhomirov, 1995)

Considering the peculiarities of the formation of nearby estates of the highest nobility around St. Petersburg, the countries of Europe and other regions of Russia were analyzed in order to identify similar unique estates. As a result of the analysis, we can conclude that the appearance of pompous, large and presentable objects, which were built for themselves by the ones close to the ruling elite, is also characteristic of European countries.

We'll give examples of some of them. For example: in France, the Villa Rothschild in Cannes and the estate of Vaux-le-Viscount; in Germany, the Concordia villa in Bamberg, the castle of Blutenburg in Munich, the castle of Hochosterwitz; in England - Howard Castle in York, Burton Manor in Yorkshire, Belton House; in Austria, Villa Hermes; in Italy, villa Aldobrandini. The study revealed that the following is characteristic of European states (with the exception of England): most of the possessions are state-owned, they have museums, national galleries, higher education institutions and other government institutions. The exceptions are estates in England, where, unlike the rest of Europe, most are privately owned. All objects are the cultural heritage of those countries where they are located and the state is trying to preserve this heritage for posterity. (Victoria Jenkins, 2018; Tony Matthews, 2017; Mihailo Grbić, 2016; Rudi Hartmann, 2020) 
In Russia, estates of the highest nobility, with the exception of St. Petersburg, are located in Moscow and the Moscow Region: Serednikovo estate; Ostafyevo estate; Manor Olgovo; Manor Sukhanovo; Manor Arkhangelsk; Kuskovo estate and others. They are located with a territorial feature and are now called the "estate ring". And also locally: in the Crimea - the Vorontsov Palace, in the Ryazan region - the Krasnoye estate, in the Tula region - the Bobrinsky estate, in the Tver region - the Znamenskaya estate. And just like in Europe, these estates are mostly state property and museums.

In the paper of Sementsova S.V., Kozyreva E.A. and Shuvaeva E.Yu. "The estates of the Highest nobility of the St. Petersburg province as a special spatial structure of the historical St. Petersburg agglomeration" the main characteristics and spatial features of estates of the highest nobility are indicated.

"Manors of the highest nobility" ("Near estates of the highest nobility") - manors that arose and developed around St. Petersburg - as a special type of mansions formed around St. Petersburg of representatives of the upper strata of the Russian nobility, created before 1917.

In the framework of the study, representatives of the highest 4 ranks (according to the "Table of Ranks", begun back in 1719, approved by the Highest Act dd January 24, 1722) (Table of Ranks, 1830) and according to the Manifesto of Inheritance (introduced by Paul I as the "Establishment of the Imperial Family" dated April 5, 1797) (The establishment of the Imperial Family, 1830). Such estates differed from a large number of "ordinary" noble estates in that they were significantly larger in size - more than 5.0 hectares, as shown by research (but most of them - tens, even hundreds of hectares), and also on the territory of estates were located not only more diverse office and auxiliary buildings (fruit greenhouses, milk stores, horse carriage houses, glaciers, etc.), but also numerous special (obviously not functional, but necessarily prestigious) elements - various "grottoes", "Hermitages with statues" , "openwork bridges", greenhouses for the cultivation of exotic plants, stables for especially thoroughbred horses and cattle, gardens and parks in artistic design according to the author's designs, ponds and lakes with special landscape outlines (in some cases manmade), complex track systems and viewports, etc.

By 1917, St. Petersburg province included 8 counties, incl. 4 suburban (closer to the city): St. Petersburg, Shlisselburg, Peterhof, Tsarskoye Selo, and 4 distant (closer to the borders of the province): from the west with the border of the province - Luga, Yamburg, Gdovsky, from the east with the border of the province - Novoladozh district. (Military topographic map of the Russian Empire, 1855)

As a result of the analysis, it is possible to reveal that in the four inner, suburban districts, by 1917, 120 estates were preserved, including in Peterhof county - 27 estates, in St. Petersburg - 32 estates, in Tsarskoye Selo - 33 estates (10 of them were located in the boundaries of district towns), in Shlisselburg - 28 estates. (Fig. 1, 2) 


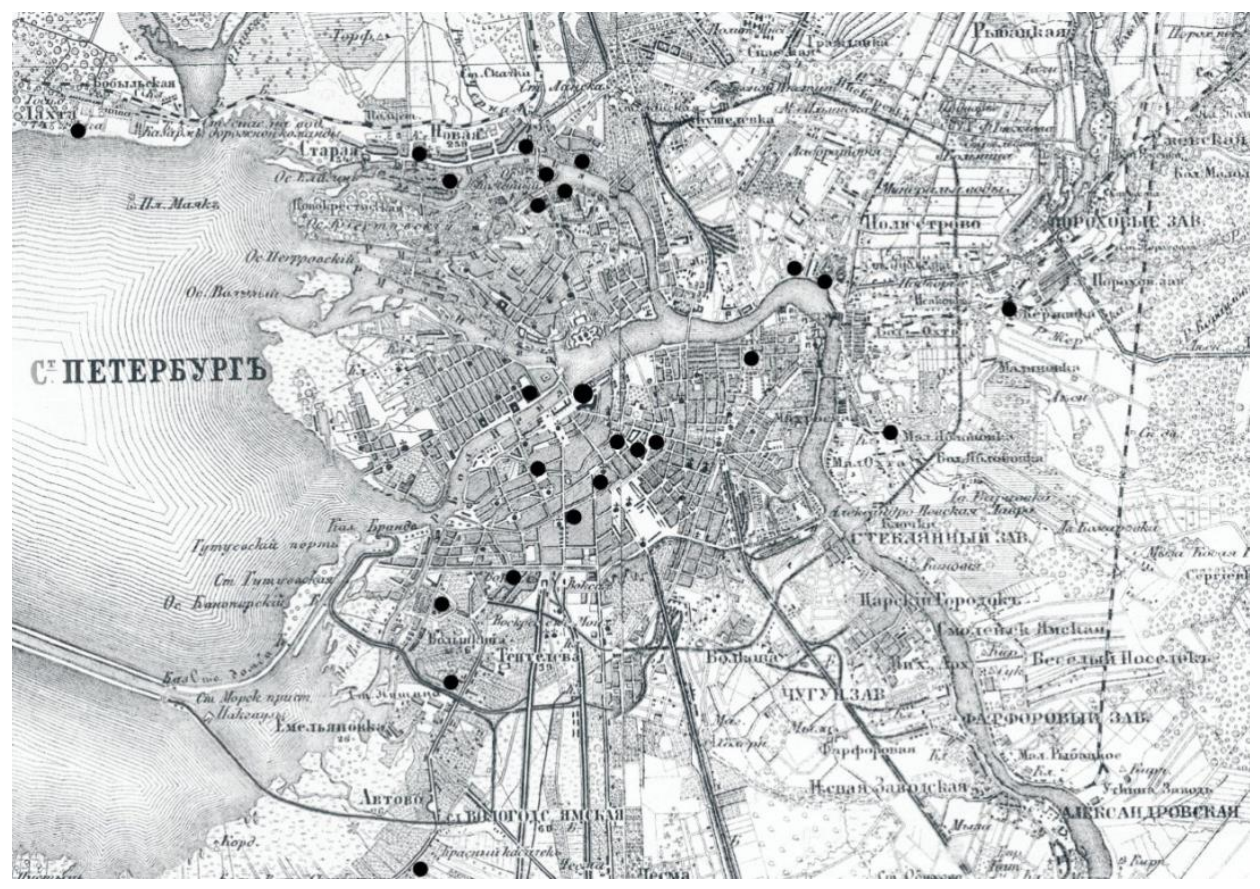

Fig. 1. 1917 Placement of estates of the highest nobility in the territories that later became part of the center of St. Petersburg.



Fig. 2. 1917. Placement of estates of the highest nobility in the territories of the neighboring districts of St. Petersburg province. 
As a result of the analysis, it is possible to reveal that the estates of the highest nobility can be divided into categories depending on the area of the estate: ordinary - up to 30 hectares, medium - from 30 to 60 , large - up to 200 hectares. It is worth noting that with the increase in the area of the estate's land plot, the number of outbuildings does not increase, however, park "joys" appear: man-made ponds, grottoes, parnassos, flower beds and other entertainment facilities. For a more detailed examination of each category depending on the area, we consider specific examples of estates.

B. Some examples of estates of the highest nobility.

The features mentioned above can be seen in the examples of four estates.

1. The estate of the Shuvalovs (of Vorontsova-Dashkova E.A.) "Pargolovo". Located in St. Petersburg County. The estate, with an area of 8621 acres and 572 square meters, included modern Poklonnaya Gora, Ozerki, Shuvalovo, the villages of Kabalovka (Kablovka or Kabolovka), Starozhilovka (Izhora or the Old Village). Currently, the estate area is 142.5 hectares, located near the Vyborg highway, is included in the administrative boundaries of the city of St. Petersburg. The city, one might say, is advancing on the estate, but historically it has been a center for the development of a suburban area. The first settlement "Parkola", later renamed in Pargolovo, mentioned in the Novgorod chronicles from 1500. For many centuries, the Pargol lands passed from hand to hand from Novgorod to the Swedes. During the Northern War, they finally passed to Russia. (Murashova, 2005)

There are 4 major stages of development of Pargolovo.

Stage 1. 1726-1745. Empress Catherine I gave it to the Vyborg commandant I.M. Shuvalov (senior) in 1726. The estate was a major, i.e. a family estate without the highest permission could not be sold or bequeathed to anyone other than members of the family of the previous owner.

Stage 2. 1746-1823. The construction of the estate complex of General Field Marshal Count P. I. Shuvalov, the youngest son of I. M. Shuvalov. During his tenure, the White House was erected, works were carried out to break down the Lower Regular Park: including the man-made Mount Parnassus, excavated ponds under it, farm buildings. By 1820, the estate under P.A. Shuvalov falls into decline and is mortgaged in the State loan bank.

Stage 3. 1823-1863. The estate is owned by V.P. Shuvalova, widow P.A. Shuvalova, and her second husband A.A. Paul. In this period, the Upper Park was created according to the project of the gardener P.I. Erler, the church of the Holy Apostles Peter and Paul was being built.

Stage 4. 1863-1917. Pargolovo is one of the most popular and lively summer cottages and environs of St. Petersburg. At the same time, the estate is finally declining. In 1877, the Partnership on Shares, for the construction of summer cottages, bought a large piece of land along the Vyborg Highway. Owners from the Shuvalov family are changing. The last owner of the estate is Countess E.A. Shuvalova, wife of Count I.I. Vorontsov-Dashkova. With her, construction works are being carried out on the site of the burnt down Grand Palace, Horse Courtyard, Farm and Gardener's House.

After 1917, the state farm "Pargolovo" was organized on the territory. After the war, since 1948, former manor buildings were transferred to the use of the Institute of High Frequency Currents (VNII TVCh).

By the beginning of 1917, there were 19 objects in the estate structure: Small Palace, Lower Regular Park, Mount Parnassus, farm buildings, Upper Landscape Park, crypt, Church of the Holy Apostles Peter and Paul, Grand Palace, Horse Building, etc. As well as ponds, including the "Napoleon's Hat" and "Napoleon's Shirt", beam alleys in the Lower Park, Stone Bench, arbors, etc. On the borders of the estate various cottages were placed.

2. Grevov's manor in Koporye, the estate's area is 45 hectares, is located in the Peterhof district near the Ropshinsky highway, $40 \mathrm{~km}$ south-west of Lomonosov and $58 \mathrm{~km}$ from 
Strelna. The lands recaptured during the Northern War Peter I granted to his associates. Extensive territories along the southern coast of the Gulf of Finland including the cities of Yam and Koporye were granted by A.D. Menshikov. Subsequently, his property was confiscated to the state treasury. The history of the estate is closely connected with the Zinoviev family, to which it belonged for more than a hundred years.

Stage 1. 1743-1809. The territory around the city and the city of Koporye were granted by Elizabeth A.G. Razumovsky. The Razumovsky family was little interested in the estate. But at the same time the estate had a flourishing appearance, a wooden church was built in the village of Koporye. (Murashova, 2005)

Stage 2. 1809-1917. The estate was bought by V.N. Zinoviev. In 1820, the architect V.I. Beretti is building a manor house and a gardener's house. From the memoirs of the emigrated Zinovievs, one can judge the great love for the estate. In the summer, the whole Zinoviev family came to the estate.

After 1917, the estate was nationalized.

By the beginning of 1917, there were 10 objects in the estate structure: a manor house, a park, a hermitage, a greenhouse, a mill, a gardener's house, an economic building, etc. As well as ponds, alleys, a willow bouquet at the eastern border, a semicircle of oaks in the northern part, etc. To date, a dense development of modern private residential buildings has arisen along the southern border of the estate.

3 Belogorka Estate, an area of 49 hectares, is located in Tsarskoye Selo Uyezd, on the banks of the Oredezh River, $60 \mathrm{~km}$ south of St. Petersburg and $44 \mathrm{~km}$ from Pushkin.

Stage 1. 1796-1799. Peter I granted territory to General P.F. Malyutin.

Stage 2. 1799-1875. The territory is bought by the leader of the nobility of Tsarskoye Selo County F.F. Belle. The estate is owned by family members.

Stage 3. 1875-1897. Repeatedly passed from hand to hand.

Stage 4. 1897-1917. A.G. Eliseev buys it for his daughter. In 1910-1912, Eliseeva built a house in the Art Nouveau style, it has survived to the present. Along the Oredezh River, she builds summer cottages, which she rents out for the summer.

In 1917, the estate was nationalized and an agricultural commune was formed.

In 1919, the commune was transformed into a state farm, and in 1925 the Leningrad Regional Agricultural Station was created here, subsequently transformed into the "Belogorka" North-West Agricultural Research Institute.

The manor house in private ownership is being restored after the 2003 fire, the territory is the state property.

By the beginning of 1917, there were 17 objects in the structure of the estate: a manor house, a park, a vegetable garden, services, farm buildings, greenhouses, orangery, a forge, a mill, a farm, barns, a horse carriage house, a priest's house, a church, etc.

4. Irinovka Manor, an area of 20 hectares, is located in Shlisselburg Uyezd, on the banks of the Oredezh River, $32 \mathrm{~km}$ northeast of St. Petersburg and $16 \mathrm{~km}$ from Vsevolozhsk. The village of Irinovka has been known since 1580, then it had the name Veringeland. (Murashova, 2005)

Stage 1. 1747-1773. Elizaveta Petrovna granted Mariselskaya Manor to the lieutenant colonel's widow Martha Sakharova.

Stage 2. 1773-1812. Irinovka and Ryabovo are sold to Baron I.Yu. Fredericks. During this period, the church of St. Irene is being built, as a result of which the estate receives the name Irinovka. Two glasswork factories and different wooden structures are also being built.

Stage 3. 1812-1840. The estate is acquired by the court adviser S. Ya. Poskochin. He leases the glasswork factories. In 1838, the estate was sold to Count P.V. GolenishchevKutuzov. 
Stage 4. 1840-1917. The estate was bought by Baron L.F. Korf. He expands and rebuilds the estate. The landscape park is also laid. In 1891-1892, a manor house was erected for Korfs according to the project of architect I.Kitner. Since 1910, the sale of land for summer cottages began in Irinovka, since 1911 glasswork, chemical and brick factories were closed. (Murashova, 2005)

After 1917, the Shlisselburg Council was located in the building for some time, since 1921 - the district Irinovsk hospital. Since 1974, it has been reorganized into the Irinovo rehabilitation department of the Vsevolozhsk hospital.

By the beginning of 1917, there were 18 objects in the estate structure: a manor house, a park, a peat briquette factory, glass plants, a church, a linden alley, a compositional dominant - a sprawling oak, etc. To date, a dense development of modern private residential buildings has arisen along the southern border of the estate.

C. Non-material aspects of estates of the highest nobility of St. Petersburg.

The study of non-physical aspects of estates nobility around the capital St. Petersburg reveals certain patterns, which are currently poorly structured and recorded in the accounting documents: the famous owners; eminent court architects, sculptors, artists and gardeners who participated in the construction; - visiting the estates by famous artists, poets, writers, politicians.

Each estate of the highest nobility was lucky to witness historical events, to "see" with their own eyes the legendary personalities. Through their works we can touch history and experience the uniqueness of these places.

\section{Discussion}

These materials are a continuation in the study and identification of a special type of claim estates located around the capital city of Russia - St. Petersburg and formed by 1917. Currently, discussions are being actively held related to the adaptation of estates and the revival of estate, as a characteristic feature of the cultural heritage of Russia.

In this regard, it is important to study how the history of formation, identification of characteristics and distinctive features of estates, including the identification and identification of a separate type of "estates of the highest nobility." The identification of patterns of formation, the impact on the urban planning and cultural life of the surrounding settlement requires additional research.

\section{Conclusions}

Thus, an analysis of the structure and morphology of the noble estates, formed during the pre-revolutionary development of the St. Petersburg agglomeration, made it possible to draw a very important scientific and methodological conclusion about the presence of their special subtype or variety - the estate of the highest nobility. These estates often (but not in all cases) were satellites of the imperial estates, and no less influenced to the structure of the settlement of service personnel and peasants, as well as the formation of summer cottages associated with them, than the imperial residences themselves. The identification of such objects and their accounting, in addition to developing the necessary scientific and methodological support for their modern use, will explain the development processes of the settlement structure in the vicinity of any historical city and prepare rational programs for the revival of abandoned, or as they say, investment-less attractive suburbs. There are examples of such involvement in the circulation of seemingly dying territories in foreign practice. For example, the revival of the traditional use and tourist attraction of the valleys of Cantabria in northern Spain. An important factor of such a revival is the actualization and active use of intangible factors woven into the legend of the object, and sometimes in the formation of a myth, which is permissible in cases where such a myth complements, but does not distort, the story. In this work, a conscious emphasis was made on these intangible 
components that are currently underexplored and underexposed components that will cause interest to the object, thus removing it from oblivion, and therefore giving it a chance for rebirth.

\section{References}

1. N.V. Murashova, Hundred noble estates of the St. Petersburg province: historical reference (SPb., Choice, 2005)

2. I.V. Barsova, Manor parks of the Leningrad region and the principles of their use. Dis cand. arch. (Leningrad, LISI, 1971)

3. S.E. Guseva, PhD Thesis (SPb., SPbGASU, 2008)

4. T.E. Isachenko, Interconnection of natural and cultural complexes of noble estates and landscape. Dis geogr. Sciences (St. Petersburg, St. Petersburg State University, 2003)

5. O.V. Litvintseva, The formation of rural noble estates of the Novgorod province of the late XVIII - XIX centuries. Dis cand. architecture (SPb, SPbGASU, 2006)

6. E.A. Kozyreva, Bulletin of civil engineers 1(54), 5-11 (2016).

7. N. Ya. Tikhomirov, Architecture of Manors near Moscow (Moscow, Gosstroyizdat, 1995)

8. No. 3890. 1722, January 24. Table of ranks of all ranks, Military, State, and Courtiers, which are of a certain class ( $\mathrm{SPb}$, Typ. of the II Department of Her Imperial Majesty Chancery, 1830)

9. No. 17906. April 1797 5. Establishment of the Imperial Family (SPb, Typ. of the II Department of Her Imperial Majesty Chancery, 1830)

10. F.F. Schubert, Military topographic map of the Russian Empire. 3 versts in 1 inch. (1855)

11. S. Sementsov, N. Akulova, Advances in Social Science, Education and Humanities Research 324, 425-433 (AtlantisPress, 2019)

12. V. Jenkins, Land Use Policy 73, 73-83 (2018)

13. T. Matthews, D. Grant-Smith, Cities 62, 152-158 (2017)

14. M. Grbić, A. Čučaković, B. Jović, M. Tripković, Journal of Cultural Heritage 18, 366369 (2016)

15. R. Hartmann, International Encyclopedia of Human Geography (Second Edition), 369372 (2020)

16. M. O. G. Stendebakken, E. R. Grytli, N. O. E. Olsson, Procedia Economics and Finance 21, 23-31 (2015)

17. J. Gil-Mastalerczyk, R. Gil, Procedia Engineering 161, 1230-1234 (2016) 